\title{
Revisiting the Debate on the Constitutionalised Status of Indigenous Languages as Language of Record in South African Judicial Proceedings
}

\author{
Nomthandazo Ntlama-Makhanya (i) \\ UNESCO “Oliver Tambo" Chair of Human Rights, Nelson R Mandela School of Law, Faculty of Law, University of Fort Hare, \\ East London, South Africa \\ Email: gatyeni20@gmail.com,nntlama@ufh.ac.za
}

How to cite this paper: Ntlama-Makhanya, N. (2021). Revisiting the Debate on the Constitutionalised Status of Indigenous Languages as Language of Record in South African Judicial Proceedings. Beijing Law Review, 12, 1077-1094.

https://doi.org/10.4236/blr.2021.124055

Received: June 14, 2021

Accepted: November 29, 2021

Published: December 2, 2021

Copyright $\odot 2021$ by author(s) and Scientific Research Publishing Inc. This work is licensed under the Creative Commons Attribution International License (CC BY 4.0).

http://creativecommons.org/licenses/by/4.0/

\begin{abstract}
South Africa's 1996 Constitution, subsequent to the attainment of democracy in 1994, was hailed as a distinct document in protecting languages, particularly indigenous languages. The inclusion of these languages generated a new lease of life and provided a unique opportunity especially for the judiciary to ensure their transmission into the legal domain by developing the scope and content and to not limit them as communication tools but also of records in the judicial processes. This role by the courts is particularly important because in the past, courts were used as instruments of oppression against the black majority of South Africa's populace. The subordination was extended to other institutions such as those of higher learning, that were handicapped in producing legal education which would infuse the African content in the generation of knowledge that may have societal change objectives. Today, the indigenous language's occupation of the constitutional space and its transmission into reality has been minotirised and subject to intense debates and views on their legitimacy as language of records in the judicial processes. The Heads of Court's resolution for the exclusive use of English as the language of record to the exclusion of other languages generated these debates. They cited logistical problems and the enhancement of access to justice that compelled them to adopt the resolution. However, the question the resolution raises is the impact it would have on the production and preservation of indigenous legal in the establishment of a "just society". Against this background, the paper is revisiting the debates on the effect of the non-use of indigenous languages as languages of records in South Africa's judicial processes through an assessment of the jurisprudence that emanates from the courts with reference to the scope and content of the interrelationship between the right of access to justice and right to understand. The objective of this paper is to advance an
\end{abstract}


inclusive approach of the language of rights that will ensure that the richness of the meanings and concepts of indigenous languages are preserved in the archives of the administration of justice. The purpose to regenerate the debate is motivated by what appears to be the subsiding deafening debates and views on the development of the content of the constitutionalised indigenous languages in the judicial processes and acceptance of the status quo of the exclusive dominance of English as language of record. The argument is limited to record-keeping and starts off by setting a framework for the protection of the right to a language and its linkage to the right to understand. The discussion is reinforced by case law relating to the use of indigenous languages and the impact it would have on the consolidation of the preservation project.

\section{Keywords}

Constitution 1996, Indigenous Languages, Human Rights, Access to Justice, Africanisation, Transformation, Social Change, Academia, Judiciary

\section{Introduction}

The Constitution of the Republic of South Africa 1996 (Constitution) was hailed as a unique document in the protection of languages, particularly, the indigenous languages, because it presented the country with 11 official languages that have all been given equal status. ${ }^{1}$ The inclusion of indigenous languages generated a new lease of life for the role, especially of the judiciary that was used an institution of oppression instead of application and interpretation of the law in a fair, impartial and without fear or favour for societal change objectives. South

${ }^{1}$ Section 6 provides that:

1) The official languages of the Republic are Sepedi, Sesotho, Setswana, siSwati, Tshivenda, Xitsonga, Afrikaans, English, isiNdebele, isiXhosa and isiZulu.

2) Recognising the historically diminished use and status of the indigenous languages of our people, the state must take practical and positive measures to elevate the status and advance the use of these languages.

3) a) The national government and provincial governments may use any particular official languages for the purposes of government, taking into account usage, practicality, expense, regional circumstances and the balance of the needs and preferences of the population as a whole or in the province concerned; but the national government and each provincial government must use at least two official languages.

b) Municipalities must take into account the language usage and preferences of their residents.

4) The national government and provincial governments, by legislative and other measures, must regulate and monitor their use of official languages. Without detracting from the provisions of subsection (2), all official languages must enjoy parity of esteem and must be treated equitably.

5) A Pan South African Language Board established by national legislation must:

a) promote, and create conditions for, the development and use of:

i) all official languages;

ii) the Khoi, Nama and San languages; and

iii) sign language; and

b) promote and ensure respect for:

i) all languages commonly used by communities in South Africa, including German, Greek, Gujarati, Hindi, Portuguese, Tamil, Telegu and Urdu; and

ii) Arabic, Hebrew, Sanskrit and other languages used for religious purposes in South Africa. 
Africa's pre-constitutional dispensation had a negative impact on other institutions such as those of higher learning in the production of legal knowledge that are designed to bring the needed change in the respective societies. These institutions were handicapped in decolonising the curricula in a way that would infuse the African content in the generation of legal knowledge that may ensure have societal change objectives. The institutions of higher learning as reservoirs in the production of "raw" legal knowledge through research and other methodologies in collaboration with the judiciary as the interpreters of such knowledge are today obligated to transform such knowledge and eliminate all remnants of the colonial and apartheid systems, which entrenched the subordinated status of indigenous languages.

In the context of the argument in this article relating the uniqueness of the inclusion of indigenous languages in the Constitution, the production of a transformed legal knowledge is of significance for the judiciary that has to ensure the development of the scope and content of such languages to go beyond being communications tools and occupy the space in record keeping in the judicial processes. In the past, indigenous languages were relegated to the sphere of national irrelevance and were used as instruments of conflict and divisions amongst black people. The Constitutional Court in the Certification of the Constitution of the Republic $1996^{2}$ also acknowledged the impact of South Africa's history on indigenous languages and held that: “... [these] languages, however, have suffered great historical neglect and are threatened with extinction”, (Certification para 211). As similarly expressed by Moseneke DCJ in the Head of Department: Department of Education $v$ Hoerskool Ermelo (2010) ${ }^{4}$ judgment:

"... of course, vital parts of the patrimony of the whole are indigenous languages which, ... languished in obscurity and underdevelopment with the results that at high school level, none of these languages have acquired their legitimate roles as effective media of construction and vehicles for expressing cultural identity", (para 49). ${ }^{5}$

This history had also a negative impact on the institutions of higher learning because it compromised their academic independence in determining "inclusivity" in the quality of the programmes they offered. Mogoeng CJ in AfriForum $V$ University of Free State $(2018)^{6}$ further gave credence to the impact of the dominance of non-indigenous languages, particularly Afrikaans on the independence of the academia and held "... sadly, all African universities and languages were deliberately starved of resources and capacities critical for a similar developmental agenda", (para 2). Broadly, the institutions were handicapped in transforming the curricula in a way that could have seen the infusion of the African content in the curriculum. The Africanisation of the curriculum project ${ }^{2} 1996$ (10) BCLR 1253 (CC).

${ }^{3}$ Certification para 211.

${ }^{4} 2010$ (3) BCLR 177 (CC).

${ }^{5}$ Ermelo, para 49.

${ }^{6} 2018$ (4) BCLR 387 (CC).

${ }^{7}$ AfriForum, para 2. 
was undermined by the use of the English language as an instrument of the suppression of the intellect of the black people.

With the inclusion of indigenous languages in the Constitution, it seemed evident that institutions of higher learning, as fountains of knowledge,

(http://wvw.ufh.ac.za/?q=centres-and-institutes/isixhosa-national-lexicographyunit-xnlu), ${ }^{8}$ would be provided with an opportunity to devise ways and mechanisms to enhance the production of legal knowledge, including their transmission into the legal domain. This meant the provision for the occupation of space and the development of their scope and content, not only as communication tools but also as tools of record in the judicial processes. This was taken against the background of the courts being used as instruments of oppression by governments of the pre-democratic dispensation, (Kgalema \& Gready, 2000).

However, these objectives were short-lived. The Heads of Courts adopted a resolution for the use of English as the only language of record to the exclusion of all other in October 2014 which came into force in March 2017. They cited logistical problems and the enhancement of access to justice as the need that compelled them to adopt the resolution. Notwithstanding the fact that they acknowledged the difficulty associated with the resolution, the resolution raises questions on the impact it would have in the preservation of indigenous languages in legal knowledge? These questions raise debates about the influence of the 1996 Constitution in the development of the content of these languages in the judicial processes.

Against this background, the paper revisits the debates on the effect of the non-use of indigenous languages as languages of records through the assessment of jurisprudence in South Africa's judicial processes with reference to the scope and content of the interrelationship between the right of access to justice and right to understand. The objective of this paper is to advance an inclusive approach of the language of rights that will ensure the richness of the meanings and concepts of indigenous languages are preserved in the archives of the administration of justice. The purpose to regenerate the debate is motivated by what appears to be the subsiding deafening debates and views on the development of the content of the constitutionalised indigenous languages in the judicial processes and acceptance of the status quo of the exclusive dominance of English as language of record.

The paper argues that the limitation of the use of indigenous languages to oral communication in judicial proceedings without transmitting them into record keeping relegates these languages to a "mere" status of no national significance. If these languages continue to fail to find space in judicial processes, the Africanisation project that should extend to the transformation of the jurisprudence from the courts is unlikely to be achieved any time soon. Further, the paper argues that the resolution which seem to be accepted even by legal academics eliminates any innovation that may be undertaken by the institutions of higher ${ }^{8}$ See the history on the establishment of the IsiXhosa National Lexicography Unit which is traceable to 1968 and finally came into fruition in 2008. 
learning for the development of these languages alongside English in the enhancement of their richness in legal production. The efforts of these institutions to Africanise the production of legal knowledge will be nothing more than a fruitless exercise.

\section{The Right to Language vis-à-vis the Right to Understand}

\subsection{Indigenous Languages: A Vehicle for Record Keeping in Judicial Processes?}

The premise upon which the argument is made here is that the rights language should be a point of departure in the protection of indigenous languages due to their universal recognition as evidenced by inclusion in many international instruments and domestic Constitutions as is the case with South Africa. The universality of the language rights captures the content of the interrelationship that exists on the right to the language itself which is of collective enjoyment and the right to understand which is individually enjoyed.

Indigenous languages are "integral and a focal point of the well-established basic human rights that are recognized world-wide", (Varennes, $2001^{9}$ ) as evidenced by their affirmation in many contemporary Constitutions and international human rights laws such as the Universal Declaration of Linguistic Rights adopted on 6-8 June 1996. As explicitly contextualised by Varennes: (ibid), language rights are closely linked to their culture which serves as a "derivative of its central location in the social and cultural identity where it does not only serve functional communication but also expresses the cultural identity of the given user and reflects the cultural heritage developed by its previous users and one of the fundamental components of human identity which is linked to the respect for a given person's identity and therefore, the language of the person", (Osiejewicz, 2017). Second, the rights language advance the pluralistic and diverse character of various communities in the enjoyment of human rights. The advantage of the rights language as Henkin (1970 in Pam: 2013) contends is that it "serves a fairly specific function as it endows a language claim with unconditional normative value and immediate applicability irrespective of local distributional consequences" (Henkin). Henkin further opines that it enjoys a prima facie, presumptive inviolability and will often trump other public goods which lie in their universal and factoid nature because they are:

1) widely recognized and the only political-moral idea that has received universal acceptance;

2) imposes external standard on states that apply to all to whom that are relevant across geography or history, culture or ideology, political or economic system or stages of development; and

3 ) it is also fact-like in the sense that both its application and its consequences are self-evidently good because once it acknowledges the existence of the right,

${ }^{9}$ Although the terminology used by reference to minority language, the concept of indigenous language as used in this article is interrelated and of no minute or fundamental difference. 
then the obligations attached to it must be adhered and observed, (Henkin).

It is evident that the concept of "language" is derived from a particular understanding that give rise to the content and meaning of a "right" as practiced and maintained by diverse groups not only in South Africa but internationally, (Dunbar 2001). ${ }^{10}$ Thus, the inclusion of the constitutional status of "language" in section 6 with its linkage to the "right to understand" as envisaged in section 35(4) is foundational to the evolution of indigenous languages which had never occupied space in legal language in South Africa. This entails the design of language within the rights framework where ordinary citizens will be enabled to access the domains and discourses that are constructive to socio-political, legal and cultural being.

South Africa's pre-democratic history limited indigenous languages to oral communication in the judicial proceedings which in turn, never gave substance to the development of the richness of these languages. Section 6 of the 1996 Constitution is very specific about the objectives of the new dawn of democracy. It seeks to ensure that these languages do not degenerate to the position they were in the past. This provision provides a framework that should capture the key content of both the right to language and the right to understand. It also encapsulates different categories that seek to advance the substantive conception of the right. These categories are derived from this provision (section 6) which entail 1) the envisaged constitutionalised status of indigenous languages; 2) the acknowledgement of the impact of the South Africa's history on the development of these languages; 3 ) the affirmation of state's responsibilities; and 4) the establishment of institutions to facilitate the constitutionalised status of these languages.

These categories are intertwined with section 9(3) of the Constitution which prohibits any form of discrimination which is based amongst other grounds: language. This means that the right to a language with its non-discrimination prescription is a yardstick for the reinforcement of a commitment which is entrenched in the preamble as it seeks to "heal the divisions of the past ... towards the establishment of a just society", (Constitution). It reinforces South Africa's pluralistic character in judicial proceedings. The interdependence of the right to language and the right to understand, especially of the indigenous languages into legal language was given a substantive conception by Hlophe JP of the Western Cape Division of the High Court. Hlophe JP contends that "language in the courts also needs to be seen within a broader context relating to transformational issues concerning the judiciary and the legal system. Because of the fundamental role of the courts in society, it is essential that they should be accessible to all. For too many years ordinary citizens have been subject to the terrifying

\footnotetext{
${ }^{10}$ Although Dunbar's focus is on minority language rights, his arguments falls within the context of indigenous languages as required to be enjoyed by people speaking the said languages. He argues that language is a fundamental constitutive element of personal identity which is an important factor in an individual's personal development. Secondly, such protection is needed of the language itself as a human rights which is not tied to an individual but a general scope for the recognition of such a language which will give rise to individual liberties.
} 
ordeal of dealing with a court situation where judicial officers and public prosecutors neither understand nor speak African languages", (Hlophe, 2004).

It is deduced from Hlophe JP's contention that the transformative quest for the use of indigenous languages as Malan points out is further characterised by the constitutionalised and indigenalised distinguishing factors that entail:

1) the limitation of the time-consuming translation of evidence, enabling the speedily conclusion of trials.

2) giving optimal way to the effective translation of the accused right into reality to the effective promotion of the right to a fair trial.

3) avoiding the misunderstanding and the resultant risk of miscarriages of justice that do in fact occur if testimony is interpreted

4) promoting more effective cross-examination, the sharpness of which is often lost when questions are translated, thus hampering the effective testing of evidence and once again the fairness of trials as such; and

5) also present an excellent opportunity to elevate the status and advance the use of the official African languages as section 6(2) instructs the state, including the courts, to do, (Malan 2009).

The afore-factors are indicative of the limitation of indigenous languages to oral communication. However, they provide an opportunity for the transmission of oral communication to record-keeping which is a key instrument in preserving the richness of the language. This is not just simply language, but legal language where indigenous languages, in the light of the transformative imperatives of the new dawn of democracy, envisions the parallel develop of their contents in the general administration of the archives of justice. Of importance is the substantive conception of the right to understand within the broader framework of the right of access to justice, (Open Society, 2016). ${ }^{11}$ The 1996 Constitution is also unequivocal in guaranteeing this right in section 34 which comprises three components with everyone being guaranteed to have the "dispute resolved by the application of the law in a fair public hearing before a court; and or where appropriate, another independent and impartial tribunal or forum", (Section 34-Constitution). This entail an affirmation of the quality of access to justice for all. They require a deep-rooted understanding of the effective way in which the language of rights in the advancement of a rights-based approach that is inclusive of all indigenous languages should evolve. The rights approach envisages a broader framework of access to justice that is not limited to the provision of legal aid and representation but to a clear understanding of procedural and substantive conception of the functioning of the courts through oral and record-keeping mechanisms. In this way, Bekink, (2016) contends that access to justice is characterised by principle of fairness in that similar cases should be treated alike; administration of the law according to the prescribed and accepted

${ }^{11}$ The paper gives effect to substantive conception of the right to access justice that it entails the 1) the nature and extent of unmet legal and justice needs and methodologies to understand people's access to justice; 2) impact of unmet legal and justice needs on individuals, the community and the state; and 3) effectiveness of specific models of legal assistance in meeting these identified needs. 
principles; conformity with the law; and treating or judging someone or something fairly (Bekink).

Nyenti, (2013) further argues:

the concept of access to justice is understood in terms of legal rights, processes and procedures. It denotes the situation where state legal systems are organised "to ensure that every person is able to invoke the legal processes for legal redress irrespective of social or economic capacity" and "that every person should receive a just and fair treatment within the legal system". This view of the concept is based on the principle that the legal system should be structured and administered in such a manner that it provides everyone with affordable and timeous access to appropriate institutions and procedures through which to claim and protect their rights. In this case, access to justice refers to the equity with which those from differing backgrounds are able to gain from the justice delivery system.

In this way, section 34 is designed to promote a rights-based approach in the advancement of the language of rights because the former (rights based-approach) seeks to ensure the inclusion of human rights integration in the adjudication of matters before the courts, the assessment of matters based on human rights norms, principles and values and the determination of the extent to which there is a fundamental and transformative change due to the infusion of rights strategies and norms in the disposal of matters, (Miller \& Redhead, 2019). The rights-based approach therefore, entails a high level of transparency wherein litigants are placed in a better stead of being able to partake in the proceedings and be well-informed in responding to the matters that may affect their liberties in the judicial processes. The transparency in this approach endorses a deeper understanding as Stoop and Churr (2013) point out that it entails the flow of information, awareness of the legal terms and but not limited to clarity of the legal language, wherein all the parties participate fully and not become "spectators in their own game." 12 Transparency, therefore, seeks to reinforce the concept of the right to "understand" which should go beyond the limitations of the legal system and involve efforts in assessing the ways in which the law promotes or impedes socio-political, legal and cultural framework in the affirmation of the language of human rights.

Section 34 reaffirms equal access to justice for all without hindrance. It is in this context that understanding legal language within the framework of language rights, which in this instance, indigenous languages become imperative. It reinforces the interrelationship that exists between the concept of understanding the language and access to justice. It is inherent for the extension of indigenous languages to record-keeping. The interrelationship responds directly to the international prescripts of human rights which are infused in the Constitution that are characterized by "universality, and inalienability; indivisibility; interdependence and interrelatedness; non-discrimination and equality; participation and inclu-

${ }^{12}$ Idiom used to indicate an importance of inclusivity in participating in the judicial processes. 
sion; accountability and the rule of law", (Miller and Redhead). Overall, the interrelationship within the rights-approach has the potential to promote the principle of representation in judicial proceedings without being limited by the language barrier. It is the quality of access justice for all without distinction based on the language of rights that may in turn advance South Africa's diverse character in the establishment of a just society as envisaged in the Constitution.

\subsection{The Still-Born Status of Indigenous Languages: Constitutional Promise Not Kept}

Notwithstanding the constitutionalised status of indigenous languages, their infusion into the domain of record-keeping remains "swinging in the pendulum". The strongly held views on the constitutionalized status of these languages and the existing need to be transmitted in all spheres and branches in order to ensure transformation of the production of legal knowledge seems to have subsided. It also appears as if South Africans have accepted the status quo of having rights on paper without their substantive translation into reality. The transmission of indigenous languages into the domain of legal language, particularly for the judiciary in its record-keeping process is made significant because of its status as the "last line of defence" in the protection of rights, (Cross, 2017).

The void of these languages in the judicial processes is first overshadowed by the oral communication itself. It appears that the constitutionalised status was still-born because of the weaknesses observed and identified in the jurisprudence of the courts. The contention is reinforced by the unfair comparison and an assessment of evidence in Williams $v$ Minister of Police (2015). What matters most in this case is the distinction made between a white and a black police officer on the quality of evidence they presented before the court. The court gave credence to the evidence presented by the white officer in English as opposed to the black officer who did not give his evidence in his own indigenous language. The court highlighted that the former was "more eloquent, polite throughout his evidence and made no attempt to dramatise or exaggerate his accounts of events ... and one would conclude that he was a credible and reliable witness whose version had to be accepted", (Williams 40). Whereas in respect of the black officer, the court "suspected he rehearsed his evidence ... became evasive and uncomfortable under cross-examination, looking, averting his gaze from anyone, spoke more softly with a distinctly embarrassed smile on his face, (Williams 41). The judge went on to state that I could not say whether that was because he was not telling the truth or whether it was because he realised just how poorly the events of that night reflected on the institution which he served, (Williams 41).

The court criticized the quality of the evidence of the black officer whose language is indigenous. The criticism was reduced to the classification of the parties and compromised the nature of the issue to be determined by the court. This approach failed to give content to language as a right which had to be transformed to the right to understand by focusing on the issue to be determined and not the classification or characterization of the parties. This is indeed a very 
"mischievous approach" that was designed to embarrass the black officer whose English was not of the standards expected by the court. It set the tone for the entrenchment of English as a superior language of both oral communication and record.

The attitude displayed by the court in Williams is closely linked to the one which was already adopted in $S_{V}$ Matomela 1998 and reinforced in $S_{V}$ Damoyi 2003 where English was elevated as a supreme language of record in judicial processes. The court in Damoyi held that:

the solution to problems on the use of indigenous languages could be the introduction of one language of record in court proceedings. I am of the opinion that the recommendation by Tshabalala J in $S_{V}$ Matomela is the route to follow, and, in my view, such a course would not only be economical but would be in the best interest of justice. After all English already is a language used in international commerce and international transactions are exclusively concluded in the English language. Although some stakeholders would take it with a pinch of salt, sanity would tip the scale in favour of English as the language of record in court proceedings, particularly in view of its predominance in international politics, commerce and industry ... these languages have the potential of costly implications in the administration of justice, (Damoyi). ${ }^{13}$ (author emphasis).

This is the approach that continue to display that indigenous languages are of no national relevance because even with the oral communication itself, the indigenisation of these languages is reduced to the questioning of the intellectual capacity for the use of the latter in the judicial processes. Their potential in permeating the local sphere of reasoning is harm strung by the considerations of the so-called "international best practices" in the use of English. The further considerations of the difficulty associated with the use of indigenous languages is an affront to what is progressively required to ensure the transformation of the judicial process through the use of indigenous language. This reasoning in $\mathrm{Da}$ moyi, waters down the impact South Africa's history had on the parallel development of all languages. It continues to classify South African citizens based on language and characterise personalities as it was the case in the past, which also manifested itself in Williams.

The further compromise to the indigenisation process is the perpetuation of the dominance of English where the right to understand does not entail the use of an indigenous language if the litigant understands English. The case of Mthethwa v De Bruin (1998) attest to this contention where Mthethwa, a school teacher, wanted to testify in his own Isizulu indigenous language but the court held that the right to understand in section $35(3)(\mathrm{k})$ of the Constitution ${ }^{14}$ does not entail the use of an indigenous language if English is understood. The interpretation given by the court relating to the substantive translation of section

${ }^{13}$ Author emphasis and footnotes omitted.

${ }^{14}$ Section $35(3)(\mathrm{k})$ provides that every accused person has a right to a fair trial, which includes the right to be tried in a language that the accused person understands, or if it is not practicable, to have the proceedings interpreted in that language. 
35(3) (k) leaves the application of section 6(2) in a "hollow ring". It does not dig deeper into the contents of the parity of languages in court processes, (Mthethwa 17). It is clear that there is no right to choose a language within which to conduct the proceedings other than a smoke-screen discretion to be exercised by the court to determine the eloquence of the party in understanding English. This understanding loses foresight that even those who understand English might not understand some indigenous terms in English. In Mthethwa, the use of indigenous languages in oral communication was thrown out of the judicial window with serious repercussions for the transformation of the jurisprudence of the court.

The idiom used above on the still-born status of indigenous languages indicates that the rights approach in the development of these languages in legal language has not even taken a "snail pace" because the translation of the constitutionalised status in the judicial process, at least in the context of oral communication, has been "dwarfed" by their reduction to personal traits. It is also the Constitution itself that has created this loophole in oral communication by not entrenching a specific provision that deals with record-keeping relating to languages in the judicial processes. The judiciary is left at its discretion to determine what it deems fit, which in this instance, the dominance of English over all other languages as further evidenced by the resolve of the Heads of Courts. The English dominance is an affirmation of the still-born status of indigenous languages because their use in the courts in giving content to the right to understand within the framework of access to justice should take into account the impact of South Africa's history where the general populace is faced by high levels of:

poverty and illiteracy abound and differences of culture and language are pronounced, where such conditions isolate the people whom they handicap from the mainstream of the law, where most persons who have been injured are either unaware of or poorly informed about their legal rights and what they should do in order to enforce those, and where access to the professional advice and assistance that they need so sorely is often difficult for financial or geographical reasons, (Mohlomi v Minister of Defence 1997; Soobramoney v Minister of Health (KwaZulu-Natal) 1997)..$^{15}$

The academic space in the production of transformed legal knowledge in institutions of higher learning has also been minotirised. These institutions are today under extreme pressure to eradicate or otherwise infuse the elements and principles of the indigenised knowledge that will reflect South Africa's pluralistic character. With the lack or flow and linkage of the information from the acade-

\footnotetext{
${ }^{15}$ The impact of South Africa's history on the enjoyment of human rights was given content by the Constitutional Court in Soobramoney v Minister of Health (KwaZulu-Natal) 1997 (12) BCLR 1696 when the Court held that "we live in a society in which there are great disparities in wealth. Millions of people are living in deplorable conditions and in great poverty. There is a high level of unemployment, inadequate social security, and many do not have access to clean water or to adequate health services. These conditions already existed when the Constitution was adopted and a commitment to address them, and to transform our society into one in which there will be human dignity, freedom and equality, lies at the heart of our new constitutional order. For as long as these conditions continue to exist that aspiration will have a hollow ring", para 8.
} 
mia through the echelons of the judicial processes, the transmission of this knowledge is unlikely to develop the content of South Africa's jurisprudence in a way that will enable the determinant of the significance of the law in changing socio-political and cultural behavior, especially with the continued manifestation of South Africa's history on the enjoyment of human rights. The holding of the rights paper, especially in a country such as South Africa that is internationally recognized for its commitment to the rights framework for the general public, it has failed the greater majority by not ensuring the indigenous languages speaker's rights are fulfilled and the production of the transformed legal knowledge that will infuse the legal development of indigenous languages alongside English.

\section{Indigenous Languages Taken off the Rails in the Archives of the Judicial Processes}

\section{Dismantling the Tools for Equal Representation in Record Keeping}

South Africa's debates on the infusion of indigenous languages into the legal discourse through record keeping in judicial processes have proved to be of a divisive nature as opposed to be of unifying the diverse population, (Harms 2012). With the projected vision of establishing a "just society and heal the divisions of the past", (Constitution) the quest for the use of indigenous languages in record keeping has widened the divide and resulted in deepened divisions. The ruler, which in the context of this article: the Heads of Courts, determined the applicable language in order to enforce the language of the law in the belief the use of language can be transmitted from above, (Harms 2012).

It is evident that indigenous languages, with the resolution adopted by the Heads of Courts, are unlikely to develop a scientific legal vocabulary that will give content and meaning to their concepts in the legal profession. The issue of indigenous languages in record keeping was left hanging in the pendulum in Damoyi with a "hope that ... it will be resolved sooner rather than later". ${ }^{16}$ This was the approach in State $v$ Feni (Review Case No: A1794/2010; High Court Case No: 24/15) when the judge held that "it is quite plain that the government is still engaged in coordinating the process of elevating indigenous languages for use in courts. The process has not reached the stage where it could be said indigenous languages should be used in Courts even when the exigencies of a matter did not demand such use", (Feni 9). ${ }^{17}$

The uncertainty over whether indigenous languages should be transmitted into the archives of the judicial process was motivated by but not limited to the:

1) need for the appellate judges to be able to read the record presented before him/her;

2) lack of sufficient development of indigenous languages for their use in the courts; and

\footnotetext{
${ }^{16}$ Damoyi para 20 (author emphasis).

${ }^{17}$ See also $S$ V Damani 2016 (1) SACR 80 (KZP) para 7. The Court in this case repeatedly affirmed the uncertainty whether indigenous languages will forever find space in judicial archives.
} 
3) lack of transcription services that may be available to the court, (Judges Matter, 2017).

The citation of logistical problems vis-à-vis the constitutional protection of indigenous perpetuates a fiction that attributes the content and meaning of these languages to a knee-jerk exercise. It is acknowledged that in a "highly multilingual society, language policies that recognize all groups put heavy constrains on a young state, particularly a developing state such as South Africa, making more difficult the development of educational materials, the propagation of laws and administrative decrees, the production of national symbols, and the coordination of personnel throughout the country", (Laitin, 1992). In the context of indigenous languages, the limitation of record keeping to the English language continues to reduce the former languages to second-class languages as it was the case in the past. This attitude is not limited to logistical issues raised by the Heads of Courts but reinforced by the courts themselves as they could not substantiate the content of the right to understand in an indigenous language other than the competency of the litigant to speak English eloquently as in Mthethwa (Soyinka, 2020).

The limitation of record-keeping to English as a language entail that indigenous languages will never be a legal discipline that emanates from the academic discourse if the judiciary perpetuates a narrative that attributes the content and meaning of these languages to logistical problems. The exclusion of indigenous languages from the sphere of record-keeping does not accord with the imperatives of section 6(2) and inhibit their constitutionalised status as envisaged in section 6(1). Such exclusion is an affront to the "people in need that are unable to present their cases effectively in their own indigenous language which should transmit to record-keeping when they bring their cases to court which then exposes the failure of the courts to fulfil their constitutional obligation", (Budlender, 2004). The non-acknowledgment of South Africa's pluralistic character in the re-building of the country in the record-keeping processes of the courts is not only unconstitutional and invalid but perpetuates the superiority of the minority rule in the legal processes through the dominance of English, (Lubbe, 2009). Holness explicitly states that "[the courts] can and should be a vehicle for a necessary positive change upon which the lives of the general populace are enhanced through their protection and promotion of their guaranteed rights not only in South Africa but human rights laws envisaged in international law", (Holness, 2013).

The adoption of the resolution limits the space and "shuts the door" (Holness) of representation in record-keeping. The terms of indigenous languages will never find space of reason in the judiciary of logistics. Representation entails equal representation and not a mere shorthand access to the principle. The resolution raises the question on the impact of oral representation in the judicial processes. Of particular significance here is the question of the intersection of indigenous languages with English and the construction that it brings to the domains in which languages and discourses that present an advancement of the 
social, economic, legal and cultural progression (Pennycook, 1998). The issue is whether it will provide an opportunity for the development of the content of the language in record-keeping. What is evident from the resolution is that it entails the lack of voice of the linguistic community in South Africa's judicial processes. The evolution of the concepts of indigenous languages should not be constrained by logistical systems but by the way in which they are legalized into the domain of legal knowledge. It is imperative that the fundamental understanding of reading and writing as presented by oral communication of the word should be translated to the preservation of knowledge in the creation of legal knowledge.

The bone of contention here is not the mere interdependence of the right of access to justice and right to understand but what indigenously defines people who speak indigenous languages in the judicial processes within the framework of the rights language as envisaged in the Constitution. Of importance, which has to be considered very strongly is the need to access indigenous languages in record-keeping that will link it to a broader project of transforming legal language. In this way, institutions of higher learning are at the helm of producing legal knowledge that is not conflated with the western view of the content of an indigenous language. For example, the reference to "indlovukazi yenkantolo" in IsiZulu indigenous language as once observed during the court proceedings is not a pure reference to a simply English translation of the "female elephant of the court" but a specific reference to a "lady or woman judge": "my ladyship" as it affirms the richness of the indigenous language. Indigenous language speakers have a firm understanding of their concepts which have to be transmitted into the archives of the administration of justice.

Furthermore, in line with the requisites of section $174(2),{ }^{18}$ the significance of the transformation project entails the move beyond the numbers and ensure its transmission to the administration in relation to the way in which the information is archived. This means that the difficulty associated with the implementation of indigenous languages in record-keeping may be minimised because there is a considerate number of the black members of the profession including the support or professional staff that have been appointed in the courts than it was the case in the past. We are seeing the diverse courts but questions arise into the content of its diverse nature relating to indigenous languages in record keeping. It is acknowledged that the appointments are also oriented towards the western conceptions of legal knowledge because of the importation of the common law concepts in the teaching of the law. However, the new status provides an opportunity for the reversal of the way in which the law is taught and how should that information and knowledge should be absorbed by the entire legal profession.

The resolution by the Heads of Courts is paying "lip-service" to the quest for the advancement of the equal treatment and parity of esteem of these languages as envisaged in section 6(4). It is not a solution to reduce the constitutional im-

\footnotetext{
${ }^{18}$ This provision requires the transformation of the judiciary by considering the race and gender profile when appointments are being made and the progress is evident in the appointment of the black members of the profession.
} 
peratives to logistical difficulties because many of the provisions in the Constitution are faced with such when it comes to their implementation. The constitutional imperatives are couched in the non-derogable prescripts of human rights. This is the case with the implementation of socio-economic rights which are even internally qualified and made subject to progressive realisation within the context of the financial muscle of the state. Heated debates and arguments were raised against the inclusion of these rights in the Certification judgment (paras 76-78). However, the court affirmed the parity of rights which today envisages a framework for their assertion in order to contradict our past in order to "inform the future, invest in our democracy, and inform constitutional adjudication and interpretation at a range of levels", (Dawood, para 35). ${ }^{19}$ The indigenisation of record-keeping cannot be justified in the name of countervailing interests which may in turn compromise the centrality of determining the impact of the Constitution in the advancement of social change.

The resolution has also resulted in the lonely death of the Use of Official Languages Act 12 of 2012. ${ }^{20}$ The Languages Act reinforced the long established Pan South African Board Act 59 of $1995 .^{21}$ The two pieces of legislation obligate the state to ensure the development of the content of the right by providing an appropriate utilisation of the constitutionalised protected rights. Hence the regulation and monitoring of the use of official languages in the Language Act and the Board Act remains an envisioned goal that has been shattered into pieces by the resolution. The resolution is a bar to the determination of the reasonableness of the measures taken to facilitate the use of indigenous languages into the legal domain. It appears that the debates and hotly contested views not only on the use of indigenous languages in court but their record-keeping have diminished. South Africans have accepted the status quo of their languages not developing alongside English to ensure not just the pluralistic character but the deeper understanding of the principles of the new dawn of democracy in their own indigenous context. The use of language should not be limited to oral right but be extended to the non-derogable right of an entitlement to a fundamental right of the right to understand which should also be preserved in the archives of the administration of justice. The resolution dismantled any opportunity that may have been presented by the constitutional occupation of indigenous languages to ensure their flourishing in the judicial processes.

\section{Conclusion}

South Africa's multi-character as evidenced by the inclusion of the indigenous

${ }^{19}$ Dawood v Minister of Home Affairs 2000 (8) BCLR 837 (CC) para 35.

${ }^{20}$ The objects of the Act are envisaged in section 2 which seeks to 1) to regulate and monitor the use of official languages for government purposes by national government; 2) to promote parity of esteem and equitable treatment of official languages of the Republic; 3) to facilitate equitable access to services and information of national government; and 4) to promote good language management by national government for efficient public service administration and to meet the needs of the public. ${ }^{21}$ See section 3 of the Act on the objects of the Board in promoting linguistic diversity in South Africa. 
languages in the 1996 Constitution has been reduced to logistical difficulties. It raises questions on whether the constitutionalised status of indigenous languages can be compromised due to the anticipated difficulties that are associated with its implementation. Traceable from the cases discussed here which are reinforced by the resolution of the Heads of Courts, it is clear that these languages are unlikely to be elevated from their reduced status as it was the case in the past in order to enjoy the parity of esteem and their equitably treatment as envisaged in section 6(2) and sub-section 4 of the Constitution. The resolution offends South Africa's linguistic character which is grounded in the 1996 Constitution. The potential to advance a rights-based constitutional order using the logic and language of rights is unlikely to be achieved because the momentum for the substantive translation of indigenous languages has been "thrown and flew out of the window".22

Overall, the inclusion of indigenous languages is a failed constitutional project that does not seem will have any potential to be transmitted through the record-keeping process of the judiciary. The jurisprudence discussed here is evidence of the legal persona who do not have any other way out to ensure the transmission of indigenous languages into language of records of the courts. The silence from all spheres, branches, and the general public about these languages in record keeping is disingenuous because mostly it is the vulnerable who are hard-hit by the litigation processes which are difficult to understand, enforcement procedures that are complex which could have been at least made easy by simplifying the process in the recording for future processes.

\section{Conflicts of Interest}

The author declares no conflicts of interest regarding the publication of this paper.

\section{References}

(1996). Certification of the Constitution of the Republic of South Africa. BCLR, (10), 1253.

(1997). Mohlomi v Minister of Defence. SA, 1, 124 (CC).

(1997). Soobramoney v Minister of Health (KwaZulu-Natal). BCLR, (12), 1696.

(1998). Mthethwa v De Bruin. BCLR, (3), 336(N).

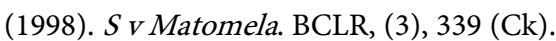

(2000). Dawood v Minister of Home Affairs. BCLR, (8), 837 (CC).

(2003). S v Damoyi. [JOL]12306 (C).

(2010). Head of Department: Department of Education v Hoerskool Ermelo. BCLR, (3), 177 (CC).

(2015). Williams v Minister of Police. ZAKZPHC 53.

\footnotetext{
${ }^{22}$ Idiom extracted from Ntlama N "The implications of the decision in Helen Suzman Foundation v Judicial Services Commission 2018 (7) BCLR 763 (CC) 8 on the functioning of the South African Judicial Services Commission" (2020) 24 Law, Democracy and Development 248-270.
} 
(2016). $S_{V}$ Damani. SACR, (1), 80 (KZP).

(2018). AfriForum v University of Free State. BCLR, (4), 387 (CC).

Bekink, B. (2016). Principles of South African Constitutional Law (2nd ed. p. 95). LexisNexis.

Budlender, G. (2004). Access to Courts. SALJ, 121, 339-358.

Cross, D. (2017). A Human Rights-Based Approach to Community Justice: Adding Value to Desistance Focused Practice. European Journal of Probation, 9, 149-168. https://doi.org/10.1177/2066220317719801

Dunbar, R. (2001). Minority Language Rights in International Law. The International and Comparative Law Quarterly, 50, 90-120. https://doi.org/10.1093/iclq/50.1.90

Harms, L. T. C. (2012). Law and Language in a Multilingual Society. Potchefstroomse Elektroniese Regsblad, 15, 21-31. https://doi.org/10.4314/pelj.v15i2.2

Henkin, L. (1970). Age of Rights in Paz M. (2013). The Failed Promise of Language Rights: A Critique of the International Language Rights Regime. Harvard International Law Journal, 54, 157-218.

Hlophe, J. M. (2004). Receiving Justice in Your Own Language: The Need for Effective Court Interpreting in Our Multilingual Society. Advocate Journal, 17, 42-47.

Holness, D. (2013). Recent Developments in the Provision of Pro Bono Legal Services by Attorneys in South Africa. Potchefstroomse Elektroniese Regsblad, 16, 129. https://doi.org/10.4314/pelj.v16i1.5

Kgalema, L., \& Gready, P. (2000). Transformation of the Magistracy: Balancing Independence and Accountability in the New Democratic Order. https://csvr.org.za/docs/trc/transformationmagistracy.pdf

Laitin, D. D. (1992). Language Repertoires and State Construction in Africa (pp. 63-64). Cambridge University Press. In Arzoz, X. (2007). The Nature of Language Rights. Journal on Ethnopolitics and Minority Issues in Europe, 6, 1-35.

Lubbe, H. J. (2009). The Right to Language in Court: A Language Right or a Communication Rights?

Malan, K. (2009). Observations on the Use of Official Languages for the Recording of Court Proceedings. Tydskrif Vir Die Suid-Afrikaanse Reg, 141-155.

Matter, J. (2017, November 21). The Use of Indigenous Languages in the Courts. http://www.judgesmatter.co.za/opinions/language-court

Miller, H., \& Redhead, R. (2019). Beyond "Rights-Based Approaches"? Employing Process and Outcomes Framework. The International Journal of Human Rights, 23, 699-718. https://doi.org/10.1080/13642987.2019.1607210 https://www.tandfonline.com/doi/epub/10.1080/13642987.2019.1607210?needAccess=t $\underline{\text { rue }}$

Ntlama, N. (2018). The Implications of the Decision in Helen Suzman Foundation v Judicial Services Commission. BCLR, No. 7, 763. (CC) 8 on the Functioning of the South African Judicial Services Commission. (2020) 24 Law, Democracy and Development 248.

Nyenti, M. (2013). Access to Justice in the South African Social Security System: Towards a Conceptual Approach. De Jure, 46, 901-916.

Open Society Justice Initiative (2016, November 3-4). Understanding Effective Access to Justice. OECD Conference Paper, Paris.

https://www.oecd.org/gov/Understanding-effective-access-justice-workshop-paper-fin al.pdf 
Osiejewicz, J. (2017). Supranational Protection of Language Rights in Universal and European Contexts (pp. 213-228).

Pennycook, A. (1998). The Right to Language: Towards a Situated Ethics of Language Possibilities. Language Sciences, 20, 73-87. https://doi.org/10.1016/S0388-0001(97)00013-2

Soyinka, A. (2020, April 16). Why Using Just One Language in South Africa's Courts Is a Problem?

https://www.ru.ac.za/latestnews/whyusingjustonelanguageinsouthafricascourtsisaprobl em.html

State v Feni Review Case No: A1794/2010; High Court Case No: 24/15.

Stoop, P. N., \& Churr, C. (2013). Unpacking the Right to Plain and Understandable Language in the Consumer Protection Act 68 of 2008. Potchefstroomse Elektroniese Regsblad, 16, 517. https://doi.org/10.4314/pelj.v16i5.12

The Constitution of the Republic of South Africa 1996.

The Universal Declaration of Linguistic Rights, 1996.

The Use of Official Languages Act 12 of 2012.

Varennes, F. (2001). Language Rights as an Integral Part of Human Rights. International Journal on Multicultural Societies, 3, 15-25. 